\title{
The Infuence of Using Android Education Application "Andre" to Adolescent's Knowledge About Drug Abuse in Senior High School 8 Kediri
}

\author{
Eny Sendra, Suwoyo, Lumastari Ajeng Wijayanti* \\ Health Polytechnic of Ministry of Health, Malang, East Java, Indonesia \\ *ajengg1612@gmail.com
}

\begin{abstract}
Drug abuse that occurs in adolescents was a problem that must be addressed. This event was marked by the number of teenagers who abuse drugs. The use of mobile phones as a learning media was a container that was often used. Android education application was a medium for health promotion to reduce the incidence of juvenile drug abuse. This study aims to analyze differences in knowledge of adolescents about drugs using the android education application at SMAN 8 Kota Kediri. The population in this study were all teenage boys and girls in class X in SMAN 8 Kota Kediri with a total of 350 students with a sample of 179 students, the sampling technique used Cluster Random Sampling. Data analysis using statistical tests WilcoxonMatch Pairt Test test results get a Zcount value of 11.409 (absolute value) with a significance of 0,000 . Because Zcount has a significance of less than 0.050 ( $\mathrm{sig}<0.050$ ), Ho is rejected and $\mathrm{H} 1$ is accepted. so that it can be concluded that there is a significant effect on knowledge before and after being given an android education application. Prevention of drug abuse needs to be supported by the role of parents.
\end{abstract}

Keywords : Knowledge About Drugs, Adolenscent, “ANDRE” Application Media

Received August 5, 2020; Revised October 3, 2020; Accepted October 26, 2020 


\section{STRADA Jurnal Ilmiah Kesehatan}

DOI: $10.30994 /$ sjik.v9i2.429

ISSN: 2252-3847 (print); 2614-350X (online)

Vol.9 No.2 November 2020 Page.1173-1180

\section{BACKGROUND}

Narcotics was a drug or ingredient that was useful in the field of medicine and services aimed at health and the development of science, while the use of outside doses without control or supervision can lead to dependence that is very detrimental to the wearer (Law Number 35,2009).

Drug abuse cases in Indonesia from year to year also continued to increase, not least with drug abuse cases in North Sulawesi Province where in year 2015 there was an increase in drug abuse as evidenced by data on drug abuse rehabilitation patients totaling 737 patients and 487 patients were teenagers who still students. The drug case data showed that the trend of drug cases was always increasing from year to year and among those who abuse drugs are students and students (BNNP Sulut, 2016). State losses reach 50 trillion per year due to drug abuse (BNN, 5/1/2015).

The role of health workers had a big influence in realizing prevention of the younger generation in drug abuse to minimize the rate of drug use among teenager, so much of the influence of drug abuse could fatal, around 40-50 people in Indonesia died every day due to drug abuse (President Jokowi to lecturers in public lectures at UGM, 12/10/2014).

In the regulation of the Republic of Indonesia National Narcotics Agency number 2 of 2018 concerning guidelines for the implementation of information and communication technology, it was explained that the implementation of information and communication technology had an important role in realizing good governance within the National Narcotics Agency.

Based on the results of a preliminary research on November 15, 2018 at the BNN in Kediri City, in year 2015 to 2017 there were 189 positive drug users. The majority of users were male and 146 people and 43 people were female. As well as the most categories of substances misused by LL (double L) with a period of 15 to 25 years, there were 68 people.

From the results of the second preliminary research by distributing as many as 176 teenagers, it was found that $100 \%$ of respondents had social media, $98,3 \%$ had mobile android support, $84,7 \%$ of teenagers accessed the internet to help with learning and 79 , $5 \%$ of teenagers preferred to learn by accessing the internet rather than having to buy a new textbook. Most by accessing lessons it was very easy in terms of cost and time effectiveness.

\section{METHODS}

In this research, researchers used a pre to post-test design in one group. This research was a quantitative study that reveal a causal relationship by involving one group of subjects. The subject group was observed before an intervention was conducted on how to understand about drugs, then the subject group would be treated with the "ANDRE" application and then observed again after the intervention. (Nursalam, 2017, p. 165).

Data collection began with managing permits to the Kediri District and City Education Service. the permit issued would be directed at Senior High School 8 Kediri City.AfterSenior High School 8 Kediri City gave a research permit, the researcher began conducting research. The researcher provided information about the research that would be conducted to the respondents. If the respondent agreed, the researcher asks the respondent to fill out the information sheet. The population of this research were all 10th grade students of Natural Sciences and Social Sciences at Senior High School 8 Kediri City as many as 358 adolescents, while the research sample were 179 adolescents with cluster random sampling. 


\section{STRADA Jurnal Ilmiah Kesehatan}

DOI: $10.30994 /$ sjik.v9i2.429

ISSN: 2252-3847 (print); 2614-350X (online)

Vol.9 No.2 November 2020 Page.1173-1180

Data retrieval was carried out using validated questionnaires dated May 10, 2019 with information passed the Review of Ethics Reg.No.153 / KEPK-POLKESMA / 2019. The independent variable in this study is the Android Education (ANDRE) application and the dependent variable is adolescent knowledge about the dangers of drug use. The inclusion criteria in this researchwere young men and women in Senior High School 8 Kediri City who were willing to become respondents and followed procedures, adolescents age 15 to 17 years, adolescents who had android cellphones, teenagers who were willing to use the" ANDRE" application according to the instructions and procedures set.

While the exclusion criteria were adolescents who not present in the research, adolescents who were sick and did not allow to take part in the research. Univariate analysis in this study was categorical data in the form of frequency distribution of the value of the pretest and posttest values of the two groups. Bivariate analysis was performed on two variables that would be suspected of being related or correlated using the Wilcoxon Matched Pairs Test.

\section{RESULTS}

General data

Table 1 Frequency Distribution Based on Age, and Sex of Class 10 Science and Social Sciences before and after Using "ANDRE" Application at Senior High School 8 Kediri City in 2019

\begin{tabular}{lcc}
\hline No $\quad$ Characteristics of Respondents & Total & Precentage (\%) \\
\hline 1. Age (Years Old) & & \\
$\quad$ 15 to 16 Years Old & 137 & 76,5 \\
2. 17 to 18 Years Old & 41 & 22,9 \\
Gender & & \\
$\quad$ Male & 72 & 40,2 \\
$\quad$ Female & 107 & 59.9 \\
\hline
\end{tabular}

Source: results data of post test in year 2019

Table 2 Frequency Distribution of Youth Knowledge Score Categories about Drug before Obtaining Treatment of the "ANDRE" (Pre-Test) Application.

\begin{tabular}{clcc}
\hline & Category & Frequency & Percentage \\
\hline 1. & Good & 12 & 6,7 \\
2. & Enough & 96 & 53,6 \\
3. & Less & 71 & 39,6 \\
\hline \multicolumn{2}{c}{ Total } & $\mathbf{1 7 9}$ & $\mathbf{1 0 0 . 0 0}$ \\
\hline
\end{tabular}

Source: results data of post test in year 2019

Table 2 showed that respondents with the criteria of knowledge about drugs in the good category were only owned by 12 people $(6,7 \%)$.

Table 3 Frequency Distribution of Categories of Scores for Knowledge of Teenagers about Drug after Obtaining the Treatment of the Andre Application (Post-Test).

\begin{tabular}{cccc}
\hline No & Category & Frequency & Percentage \\
\hline 1 & Good & 161 & 89,9 \\
\hline 2 & Enough & 15 & 8,3 \\
\hline
\end{tabular}




\section{STRADA Jurnal Ilmiah Kesehatan}

DOI: $10.30994 /$ sjik.v9i2.429

ISSN: 2252-3847 (print); 2614-350X (online)

Vol.9 No.2 November 2020 Page.1173-1180

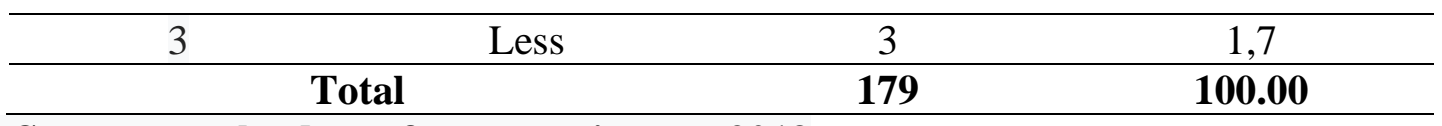

Source: results data of post test in year 2019

Table 3 showed that the majority of respondents, namely 161 people $(89,9 \%)$ had knowledge of drugs in the good category.

Table 4 Frequency Distribution of Adolescent Knowledge about Narcotics before and after using the ANDRE Application at Senior High School 8 Kediri City.

\begin{tabular}{ccccccc}
\hline \multirow{2}{*}{ No } & Knowledge & $\begin{array}{c}\text { Before was given } \\
\text { Application }\end{array}$ & $\begin{array}{c}\text { After was diven } \\
\text { Application }\end{array}$ & Z Z \\
\cline { 3 - 6 } & F & \% & F & \% \\
\hline 1 & Good & 12 & 6,7 & 161 & 89,9 \\
\hline 2 & Enough & 96 & 53,6 & 15 & 8,3 & \\
\hline 3 & Less & 71 & 39,6 & 3 & 1,7 & \multirow{1}{*}{11,407} \\
\hline & Total & $\mathbf{1 7 9}$ & $\mathbf{1 0 0}$ & $\mathbf{1 7 9}$ & $\mathbf{1 0 0}$ & \\
\hline
\end{tabular}

Source: results data of post test in year 2019

$\mathrm{Z}_{\text {count }}$ was obtained using the Wilcoxon Match Pairs Test. Price (-) was not calculated because of the absolute price.

Based on table 4, it could be seen that the comparison of knowledge before and after was given the application had a significant increase in scores, this data was strengthened with the results of the Wilcoxon test calculation using the social science statistical program assistance to obtain a $Z_{\text {count }}$ value of $-11,407$ (absolute value) with a significance of 0,000. Because $Z_{\text {count }}$ had a significance of less than 0,050 ( $\left.\mathrm{sig}<0,050\right)$, then $\mathrm{H}_{\mathrm{o}}$ was rejected and $\mathrm{H}_{1}$ was accepted, so it could be concluded that there were significant differences in knowledge before and after was given android education application. Learning outcomes using android education application there were influenced before and after the application were given.

\section{DISCUSSION}

1. Identifying Adolescent Knowledge of the Use of Psychptropic Narcotics and other addictive substances (drugs)

The results of knowledge about drugs found that the lack of knowledge of adolescents in Senior High School 8 Kediri City, with the criteria of lack of knowledge were $39,1 \%$. This number were quite dominant of the total respondents. This data was continuous with the researchers' preliminary research on November 15, in year 2018 at the Kediri City National Narcotics Agency explained that there were 189 positive drug abusers.

Lack of knowledge was a factor in the occurrence of drug abuse in the City of Kediri, this data was strengthened from the results of the pretest conducted by researchers who proved that the lack of knowledge of adolescents about drugs. It was proven in a research conducted by Tri Prastidini et al (2018) about the description of adolescent knowledge and attitudes towards drugs, explained that in the Babakan Sari area in the last 3 months there were Two drug abuse among adolescents.

The majority of adolescents who were already high school, attend high school 16 Bandung, from the results of interviews conducted with one of the counseling staff said that this high school did not get too much counseling about drugs. Knowledge 


\section{STRADA Jurnal Ilmiah Kesehatan}

DOI: $10.30994 /$ sjik.v9i2.429

ISSN: 2252-3847 (print); 2614-350X (online)

Vol.9 No.2 November 2020 Page.1173-1180

was important, so that teens could avoid drugs, with them knowing the types and preparations of drugs at least able to avoid exposure to the negative effects of drugs, the number of victims due to drug abuse wasthe fact that this problem need addressed.

Based on a research journal in year 2017 conducted by Emmanuel OkechukwuChukwu et al entitled "Effects of Substance / Drug Abuse on the Academic Achievement of Secondary Schools Students in Metropolis Metropolis, Gboko, Benue State" from the journal described institutionalizing early detection programs in schools would be major prevention or solutions to reduce the level of substance or drug abuse.

Recommendations made that include drug-free substance clubs must be established in secondary schools, counseling education must be introduced to secondary schools and must involved parents and guardians, design drug education curriculum, etc. Emphasis should be placed on health education because this would help families in planning the academic future of their children, family and nation.

2. Results of Descriptive Analysis of Data on Adolescent Knowledge about Psychptropic Narcotics and Other Addictive Substances after was Given the Treatment of Android Education Application (ANDRE).

The results of the study were conducted on April 18 to April 302019 at Senior High School 8 Kediri City. It was explained after the respondents used the android education application there was an increase with the good criteria of $89,9 \%$.

Data collection used in this researchwas primary data. Primary data was data obtained through observation and data collection tools using a validated questionnaire.

Based on observations made by researchers, the increase in knowledge occurred after using the android education application, the use of mobile phones was used as a learning media used in daily activities not to burden teenagers' activities.

The evaluation results obtained by the application of android education were used in the intervals of the teenagers' busyness. The use of the application were carried out when teenagers are waiting in line, waiting for something or on the way, the android education application could accompany them at these times. The results of open questions were also obtained when mobile phones did not have internet, usually teenagers did not know they would be busy.

The advantages of the Android education application that did not add quota to access make mobile use very useful at such times. Enthusiastic adolescents who wanted to know about drugs are the cause of adding to the post test results of adolescent knowledge of drugs, because adolescence were a time when curiosity about new things were very high, the post test results also explained the average teenager had good knowledge.

This research was in line with the research conducted by RestiaraWiyani in 2018 about the effect of giving counseling to the knowledge of early adolescents about the dangers of drugs in statedof Madrasah 1 class $X$ in Malang City obtained in the collection of research data most of the knowledge of respondents before counseling and after counseling there were increase value, this explaination that there were influence between giving counseling to the knowledge of early adolescents about the dangers of drugs in statedMadrasahAliyah 1 Class X in Malang City.

This research was in line with carried out by the Jumaidah in 2017 on the prevention behavior of drug abuse in adolescents in the Sukmajaya District, Depok. Based on the results of the study there was a relationship between knowledge and 


\section{STRADA Jurnal Ilmiah Kesehatan}

DOI: $10.30994 /$ sjik.v9i2.429

ISSN: 2252-3847 (print); 2614-350X (online)

Vol.9 No.2 November 2020 Page.1173-1180

preventive behavior, which means that there was a relationship between the environment and prevention behavior knowledge had a significant influence on preventive behavior.The higher the knowledge of adolescents, the higher the prevention of drug abuse.

From an international journal entitled "Longitudinal influence of alcohol and marijuana used academic performance incollege students" in 2017 by Shashwath et al. Explained that the combination of alcohol and the effects of marijuana could pose a threat to college GPA. The situation showed serious implications for academic performance when these two substances were commonly used when attending college. Consuming these two substances could reduced thinking power and academic performance.

From the description above,it could be concluded that the using of android applications could prevented the occurrence of drug users in adolescents, android education applications also affected the increase of knowledge in adolescents, by increasing knowledge in adolescents could minimized the occurrence of drug abuse negative influence of drug use could reduced teenagers' thinking and achievement . With the existence of supporting applications as a means of information could minimize adolescents affected by drugs.

3. Analyzing the Relationship of Using Android Education (ANDRE) to Adolescent Knowledge about Drugs.

The calculation results from 179 respondents of class X students in state high school 8 Kediri City, researchers used the Wilcoxon Match Pait Test on respondents who used the android education application. To simplify the hypothesis test, the research hypothesis was operationalized become the null hypothesis (Ho) and the alternative hypothesis (H1) was the conclusion of the hypothesis test using the significance value criteria from $\mathrm{Z}$ count.

Following were the conclusion criteria for hypothesis testing. The results of the Wilcoxon test calculation using the help of the social science statistical program got a $\mathrm{Z}$ count value of -11.407 (absolute value) with a significance of 0,000 . Because $\mathrm{Z}$ count had a significance of less than 0,050 ( $\mathrm{sig}<0,050$ ), then Ho was rejected and H1 was accepted, so it could be concluded that there were significant differences in knowledge before and after was given an android education application.

Android education application was one form of android-based educational media that could help extension agents to achieve the goals of health promotion activities. The effectiveness of the using of android applicationbased educational media had been proven by several previous research based on international journals on the "Evidence of Gaps in Adolescent Health Interventions for Rescuing Youth" conducted by OverlayJasK.DasM.D et al.

In 2016 described drug abuse, could minimize the influence of schoolbased interventions. Schoolbased primary prevention programs were effective for avoiding adolescents from drugs. In this research also explained that internetbased interventions need developed in drug prevention research. Various delivery platforms, including digital platforms and policy initiatives, had the potential to increase the results of drug abuse among teenagers.

This understanding was also proven in an international journal entitled "Efficacy of a mobile phonebased lifeskills training program for substance use prevention among adolescents: a study protocol of a cluster-randomized controlled trial" by 


\section{STRADA Jurnal Ilmiah Kesehatan}

DOI: $10.30994 /$ sjik.v9i2.429

ISSN: 2252-3847 (print); 2614-350X (online)

Vol.9 No.2 November 2020 Page.1173-1180

SeverinHaug et al in year 2018 conducted in 1312 students between the ageof 14 and 16 about 100 high school classes described Life skills training carried out in effective school curriculum to prevent the onset of drug use among teenagers. Life skills training provided through cell phones represents more economical training and a measurable approach. The main objective of this planned researchwas examined the efficacy of mobilebased life skills to prevent drug using among adolescents in a controlled trial.

Theoretically, education that utilizes an android (smart phone) based application could facilitated target subjects to capture and understand the messages conveyed. Based on an international journal entitled "The CLIMATE schools combined study: a cluster randomized controlled trial of a universal Internetbased prevention program for youth substance misuse, depression and anxiety" by Maree Teesson et al in 2014 conducted at secondary schools in New South Wales, Western Australia and Queensland, it was found that internetbased programs for the prevention of adolescents against drugs (CSC) had the potentialreduced drug use, and reduce levels of anxiety and depression at a higher level than both.

The test results above, and descriptions of several journals explained the using of information media as a preventive effort had benefits to prevent adolescents from drug abuse. The using of digital media was also necessary with adult supervision, so that teens were wiser in using information tools. Knowledge of adolescents before and after was given an android education application, had a significant difference.

There was an increasing in knowledge before and after being given. This situation explained the application of android education applications had an influence in preventing adolescents against drug abuse. Because the android education application had been produced applied to students of Senior High School 8Kediri City, the method of adding drug material to teenage students such as the application of android education could also applied to other schools in areas that were proned to drug abuse in students, android education applications could easily spread to anyone, not only teenagers in Senior High School 8 Kediri City, of coursethe purpose of this application wasreduced drug abuse, especially in teenagers.

\section{CONCLUSION}

Knowledge of drugs in adolescents before using the "ANDRE" application, which was almost half had a lack of knowledge. Knowledge of drugs in adolescents after using the "ANDRE"application, thatwas almost all teenagers had a good level of knowledge. The using of andoid education "ANDRE" application affected the knowledge of drugs in Senior High School 8 Kediri City. 


\section{STRADA Jurnal Ilmiah Kesehatan}

DOI: $10.30994 /$ siik.v9i2.429

ISSN: 2252-3847 (print); 2614-350X (online)

Vol.9 No.2 November 2020 Page.1173-1180

\section{REFERENCES}

ASTI, Y. (2014). Hubungan Pengetahuan dan Sikap Terhadap Perilaku Penyalahgunaan Narkoba pada Siswa/I SMP Negri \$ Kecamatan Pontianak Timur Kotamadya Pontianak. Fakultas Kedokteran Universitas Tanjungpura Pontianak.

Hidayat, A. A. (2010). Metode Penelitian Kebidanan Dan Teknik Analisis Data. Jakarta: Salemba Medika.

Nazzruddin. (2012). Android Pemrogaman Aplikasi Mobile Smartphone Dan Tablet PC Berbasis Android. Bandung: Informatika Bandung.

Mamangkey, B. C., Tucunan, A. A., \& Kolibu, F. K. (2016). Hubungan Antara Pengetahuan dan Sikap Dengan Tindakan Pencegahan Penyalahgunaan Narkoba Pada Kelompok Remaja Desa Dumoga I Kecamatan Dumoga Kabupaten Bolaang Mongondow. Fakultas Kesehatan Masyarakat Universitas Sam Ratulangi Manado.

Nursalam. (2017). Metodelogi Penelitian Ilmu Keperawatan. Jakarta: Salemba Medika.

Sugiyono. (2017). Statistik untuk Penelitian. Bandung: Alfabeta.

Tri prastidini. 2018. Gambaran Pengetahuan dan Sikap Remaja Terhadap NAPZA di SMAN 16 Bandung

RestiaraWiyani. 2018 Pengaruh Pemberian Penyuluhan Terhadap Pengetahuan pada Remaja Awal Tentang Bahaya Narkoba di Madrasah AliyahhNegri 1 Kelas X Malang

Jumaidah. 2017 Perilaku Pencegahan Penyalah gunaan Narkoba Pada Remaja di Wilayah Kecamatan Sukmajaya Depok

OverlayJasK.DasM.D. 2016 Evidence of Gaps in Adolescent Health Interventions for Rescuing Youth jurnal Internasional.

Saverin Hug. 2018 Effiacy of a Mobile Phone-Based Life Skills Training Program ForSubtance Use Prevention Among Adolescent: Study Protocol Of a ClusterRandomised Controlled Trial"

Maree Teeson. 2014 The CLIMATE SchollsCombineed Study: A Cluster Raindomised Controller Trial Of A Unoversal Internet-Based Prevention Program For Youth SubtanceMisue, Depression and Anxiety.

Undang-undang dasar tahun 2009 tentang narkotika

Peraturan Badan Narkotika Nasional. 2015

Peraturan Pemerintahan Kesehatan. 2017

Peraturan Badan Narkotika Nasional Tahun 2018 tentang pedoman penyelenggaraan teknologi informasi dan komunikasi

Aji\&Dwi. 2017 Pengembangan Media PembelajaranMemahamidanMemeliharaSistem Starter TipeKonvensionalBerbasisBuku Digital Electronic Publication (Epub)

Rosita. 2017 PengembanganBahan Ajar E-Book Interaktif pada Materi Sistem Pencernaan Manusia untuk Menumbuh kembangkan Keterampilan Berfikir Siswa

Emmanuel OkechukwuChukwu .2017Effects of Substance/Drug Abuse on the Academic Achievement of Secondary School Students in Mkar Metropolis, Gboko, Benue State

Shashwath. 2017Longitudinal influence of alcohol and marijuana use on academic performance incollege students. 